\title{
Traumatised between culture and religion: Women's stories
}

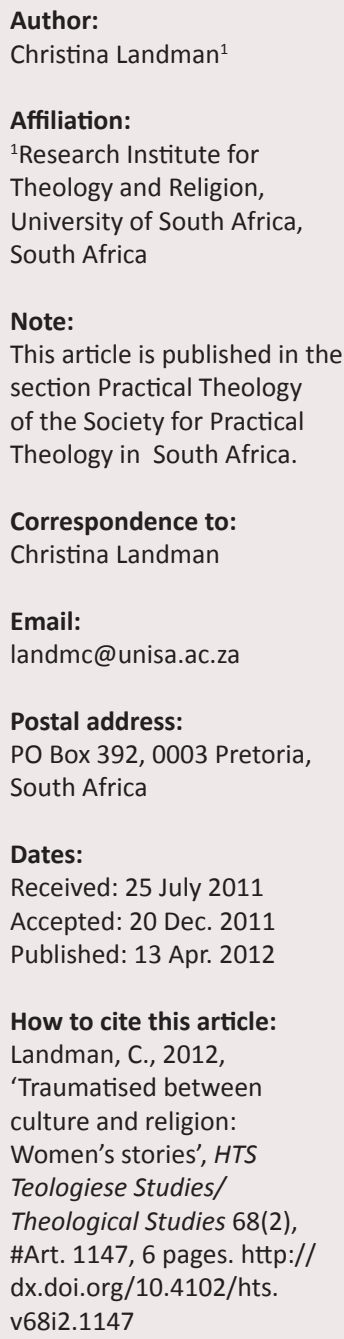

The majority of churches in South Africa offer some form of healing, be it diaconal, ritual or faith healing. Western and township views on healing differ significantly in terms of the natural and supernatural causes of and cures for illnesses. This article tells the stories of township women who were trapped between the binaries presented by Western, cultural and township healings, and their choicelessness in terms of abortion, adoption, abuse, death and sex. Through narrative counseling, based on social construction theories, the women experienced healing by exploring the healing spaces between the binaries of cultural contexts and Western medicine, through the liberty afforded them by the perspective of a preferred way of being.

\section{Introduction}

The aim of this article is to tell the stories of women, both Black and White, who find themselves in a twofold trap, namely that these women are torn between the healing offered by their churches and the restrictions of their cultures. Also, they are trapped between Western concepts of healing and those prevalent in the township, especially amongst Christian sangomas. ${ }^{1}$

This aim of this article is realised as follows:

- Firstly, there is a brief description of the movement in churches in South Africa towards spiritual healing.

- Secondly, in contrast, there is a description of views on illness and healing held by Western psychologies, township spiritualities and Christian sangomas.

- Thirdly, there is the main part of the article, which presents the stories of women trapped between religion and culture, and between Western, township and traditional cultures.

\section{The movement in South Africa towards spiritual healing}

Within a period of five years (between 2001 and 2006), the mainline Protestant churches (the Reformed, Anglican and Methodist churches) lost $26.2 \%$ of their members. ${ }^{2}$ What is significant is that these churches lost their members to churches that offer some kind of healing. These 'healing churches' are the Roman Catholic Church, ${ }^{3}$ which offers diaconal healing through food packages and hospices, charismatic churches, ${ }^{4}$ which focus on faith healing, and African independent churches, ${ }^{5}$ which offer a combination of faith and ritual healing.

In this article it will be argued that inculturated churches, such as the above, do contribute to the healing of traumatised women, but often force them into decisions and commitments that intensify their trauma. It will also be indicated that a culture-sensitive approach to narrative counselling may cause the trauma of women torn between culture and religion to disappear, or may at least alleviate it.

\section{Western views, and those of the townships and the sangomas, on healing}

In 2002-2003, under my own leadership, ${ }^{5}$ research was carried out, for the Research Institute for Theology and Religion of the University of South Africa, on the matter of healing practices. This

1.The author worked part time as a counselor at Kalafong Hospital in Atteridgeville and finished a DTh in Practical Theology at the University of South Africa in 2008 with a thesis entitled, 'Doing narrative counselling in the context of township spiritualities'. Permission to publish these stories was obtained from the women (the women's real names were not used).

2.According to the University of South Africa's Bureau for Market Research.

3.Membership of the Roman Catholic Church in South Africa increased from 2290287 in 2001 to 2657159 in 2006.

4.Membership of charismatic churches in South Africa increased from 2223515 in 2001 to 2603735 in 2006

5.Membership of the Zion Christian Church (ZCC), one of the largest African independent churches in South Africa, alone increased from 3549155 in 2001 to 5099010 in 2006. 
involved interviews with representatives of 102 churches in Atteridgeville ${ }^{6}$ and the attendance at a number of faith and ritual healings. This research enables the author to here juxtapose Western concepts of illness and healing with those of the township, and to include interviews with women in the township who call themselves 'Christian sangomas'.

A literary study of the works of Western psychiatrists, psychologists, psychotherapists and pastoral theologians, such as Wayne Oates, ${ }^{7}$ Allen Bergin, ${ }^{8}$ Robert Lovinger ${ }^{9}$ and Geri Miller ${ }^{10}$ reveals that Western psychologies view religion itself as something that can make people ill. According to those authors, religion is harmful if it is authoritarian in nature, makes you think of nothing but sin, expects God to react to your good behaviour, blames the devil for your mistakes, leads to spiritual abuse, makes you use the Bible for all your decisions, inhibits your growth, keeps you from accepting your fate, and hinders a person from adapting to their circumstances.

Spirituality however is incorporated more and more into the healing practices of Western psychologies. In summary the above-mentioned authors say that religion makes you healthier if it results in self-criticism and moral consistency, develops your human potential, lets you take responsibility for your actions, helps you to develop strategies for handling stress, and develops your ability to give and receive love. Religion is healthy if it helps you to become sensitive to the feelings of others, to understand that life has meaning, to be open and honest, to wish to work, to discipline yourself as far as alcohol and drugs are concerned, to be loyal to your partner, to be committed to your family's needs, to respect other people, to forgive yourself for mistakes you have made, to forgive your parents for their mistakes, to understand yourself as a sexual being, and to have sex only with a consenting adult partner. Religion makes you healthier if it supports you through a crisis, provides you with sources for coping with life, gives you peace, makes you understand your situation, and gives you comfort if you are afraid or in pain.

In short, in terms of Western psychological healing practices, religion is seen as either harmful or healing in the type of meaning it gives to life, the morality it incites, and the skills for handling losses that it enhances.

Township spiritualities, on the other hand, have a very different view on religion and its healing potential. This came to the fore during the above-mentioned research, when several healing ceremonies were attended and representatives

6.Atteridgeville is a "township' 13 kilometres outside the CBD of Pretoria/Tshwane in northern Gauteng, South Africa.

7.Wayne E. Oats, 1970, When religion gets sick, Westminster, Philadelphia, PA.

8.Allen E. Bergin, 1988, 'Three contributions of a spiritual perspective to psychotherapy and behavior change', in W.R. Miller \& J.E. Martin (eds.), Behavior therapy and religion, pp. 25-36, Sage, Thousand Oaks, CA.

9.Robert J. Lovinger, 1990, Religion and counseling: The psychological impact of religious belief, Continuum, New York.

10.Geri Miller, 2003, Incorporating spirituality in counseling and psychotherapy, Wiley, Hoboken, NJ. of 102 churches in Atteridgeville were interviewed. Of these 102 churches 35 were classical mainline churches, 11 were classical African churches, 4 were classical Pentecostal churches, 20 were Zionist or Apostolic churches, and 32 were 'born-again' (that is new African charismatic) churches.

Although these churches offer a variety of healing practices, it seems that they agree that it is not religion that makes a person ill. They, in fact, believe the following, that mental illness and misfortune are caused by the curse of a sangoma, which is real, even for committed Christians. Physical medical problems that are visible, such as broken bones and skin diseases, are caused by personal sins, that is, by immoral behaviour, a lack of commitment to God and slackness as far as prayer is concerned. These illnesses are also caused by structural sins such as poverty, racism, sexism, culture, secularisation, and by not being Christian enough. Physical medical problems that are not visible, such as headaches, strokes and HIV, are induced by demons, by Satan, and as a punishment by God.

Every indigenous church in the township has its own claim to healing. A church is led by a prophet or prophetess, who is an appointed healer through divine vision. Sometimes a prophetess will call herself a 'Christian sangoma'. Healing is effected through 'Biblical counselling', prayer, and the laying on of hands, but mainly through indigenous cleansing procedures that are, as said, typical of a specific church and its prophet. This cleansing includes both outer cleansing, such as bathing in water with ashes that have been blessed, and inner cleansing by drinking water with tea or coffee and small stones till vomiting occurs. Demons are identified through nests, mirrors, candles, cards, sticks and herbs. Persons can contribute to their healing only through prayer, a clean lifestyle, faith and repentance, whereas the healing itself is effected only through a healer, who may be a prophet, a pastor or a Christian sangoma.

What follows is a brief description of interviews with three healers on the topic of healing practices.

The first interview was with Bishop Mashudu Thandi Ngwenya from the Bethal Apostolic Church in South Africa, who calls herself a Christian sangoma. According to Bishop Thandi healing is effected as follows, nests and mirrors are used to point out the cause of the believer's illness. Bones are thrown and cards are used to prophesy the fate of the believer. Finally God and the ancestors, using dreams and visions, reveal to the Bishop how the suffering believer may be cured.

The second interview was with Prophet Evelyn Morotoba from the St Johanna Apostolic Church in South Africa. Prophet Evelyn lights candles for God to better hear her prayers for healing. Sewasho [ashes] and water are used for outer cleansing, and vomiting for inner cleansing. Prophet Evelyn does not use muti [herbs]. She uses the Bible to guide her when advising people on how to handle their problems. 
People who are not at peace with the ancestors are ordered to sacrifice goats. The prophet may be identified as a healer who prays whilst holding a steel rod in her hand.

The third interview was with Pastor Ngoepe, leader of the Fire Bible Church. Pastor Ngoepe was born into the Dutch Reformed Church, but at a young age left that church to become a traditional sangoma. After 25 years she rejected that type of healing, stopped being a sangoma, and started her own church, where she specialises in healing true believers, relying only on God's guidance through visions after the laying on of hands. Pastor Ngoepe has also rejected both Western medicine and the mixing of Christian and cultural healing, claiming that muti and the Holy Spirit do not mix. The pastor insists that new converts to her church throw away the Western medicine that they received from the hospital, as well as uniforms worn whilst attending other indigenous churches.

For the final and main part of the article it will be presupposed that inculturated churches, such as those described above, do contribute to the healing of troubled women, but often force them into accepting forms of healing that intensify their despair. It will be indicated how women have experienced healing through counselling aimed at deconstructing harmful religio-cultural discourses. This was done by exploring the dialogical spaces between binaries, in these cases culture on the one hand and Christianity on the other, as well as Western culture on the one hand and indigenous culture on the other.

\section{Trapped, and healed: Women's stories}

For this part of the article, in which the stories of traumatised women trapped between Western and indigenous cultures and religion are told, it is presupposed that a person becomes healthier if he or she is assisted to deconstruct harmful religious and cultural discourses, that keep him or her trapped in psychosomatic illness. The deconstruction is carried out by exploring the dialogical spaces between binary knowledge systems, in this case between Western and township spiritualities.

Apart from being involved in the above-mentioned research on healing practices in Atteridgeville the author also worked as a narrative counselor, between 2000 and 2007, in the outpatients department of Kalafong Hospital, a state hospital in Atteridgeville. The following are stories of women counselled in this setting, whose trauma was intensified by their binary experience of Western and indigenous culture, as well as the opposing cultures of tradition and Christianity.

\section{Traumatised by culture: The death of a child}

When Botle (28) was seven months pregnant, she came to the hospital because she had high blood pressure, only to find out that the baby that she was carrying had been dead for two months. Instead of the baby, the enemy came to stay with her. The name of the enemy was 'Isolation'. Botle was isolated by her husband, whose Tshwana tradition forbade him to mourn the birth of a still-born baby. Botle had to give birth to the dead baby, alone. It was a boy. She saw him. He weighed more than $500 \mathrm{~g}$ and was legally declared a person. Botle had to make arrangements for, and attend, the baby's funeral, held by her church, alone. She had to mourn the baby and deal with her loss, alone. Her husband never mentioned the baby. He never spoke about his feelings. Botle found this situation particularly difficult because she and her husband were both committed and church-going Christians.

How would we lessen the effects of Isolation on Botle's life? Botle said that there was one topic that her husband talked about, namely, having another baby. But she was too scared to attempt to have a baby at that stage, lest the pain and isolation return. Botle went to see the pastor of her church, who advised her to abandon 'cultural nonsense' in her life and have other children, as God commissioned her, as a woman, to do.

We mapped through Botle's life to find previous instances when she had been scared, but had overcome her fears and had successfully ventured onwards in her life. Botle quite spontaneously remembered a crisis experienced when she was in matric. She had failed three subjects and her parents could not afford to send her back to school. Her brother offered to pay for her studies, on condition that she would pass. Botle was scared but accepted the challenge, and succeeded.

Overcoming her fear of the effects of Tradition and Isolation on her life was Botle's first step of resistance against Tradition. We then wrote a letter to her husband, inviting him to join her healing process as a significant other.

Botle's husband accompanied her to our next counselling session. When he became aware of the role played by Isolation in Botle's life, Botle's husband was determined to end its influence. He undertook to visit the baby's grave with Botle on their way home, where they would have a private Christian ceremony consisting of prayers and the laying of wreaths. The husband also suggested that Botle take up a job in his business where she could be close to him, which would result in them not feeling isolated from each other. Now that he had shifted the discourse on tradition, he suggested that Botle do something traditional, that she should visit his aunt whose first baby had been still-born, but who had subsequently given birth to four healthy children.

This, then, is the story of a woman both trapped and healed by culture and tradition, and who found peace amid the healing offered by both religion and culture.

\section{Traumatised by culture and church: Abortion}

Khensani had had an abortion because she could not afford to raise a child at the time of her pregnancy. She complained that she had been convinced by 'Western-minded people' to have the abortion, but that it was against her culture, and 
also against the morals of her church. Because abortion was against the prescriptions of her culture, she had experienced bad dreams sent to her by the forefathers. Also, Khensani's church had reprimanded her for having the abortion and had disciplined her. Khensani then considered herself a bad person.

How can she face life again if she is rejected by her own culture and if her church says that she is a bad person? During counselling we externalised 'I am a bad person' as the problem keeping Khensani trapped in depression and trauma. We slowly sifted through her past and identified the times when Khensani had honoured her culture, when it made reasonable demands on her, and also the times when she had acted as a good Christian. For instance, after the birth of her first child she had adhered to both cultural and Christian demands by staying in her room for five days, till the scab had fallen off the child's navel, as demanded by her culture. And after three months she had the baby baptised in her church. Khensani also identified times when her life had been too much influenced by 'Western minds'.

This, then, is the story of a previously traumatised woman who became stronger when she could distinguish between the good advice of common sense, the bad advice of Westerners, and the sound demands of culture and church. She was no longer a 'bad person', but a person who could make good decisions amid the demands of Western culture, traditional culture, and church.

\section{Traumatised by culture: Adoption}

Mmankwati was 30 weeks pregnant. She was the single parent of two other children, or rather a 'double parent', because the father of the children was not involved in their upbringing. Mmankwati struggled to survive financially, and the new pregnancy, the result of a date rape, was unplanned.

Mmankwati had considered having an abortion, but her culture and her church were much against it. As her pregnancy was in too advanced a stage, abortion was out of the question.

The nurse at the hospital had tried to pursuade Mmankwati to give up the child for adoption, which is something regarded by Mmankwati's family as a 'Western concept'. At the same time, however, Mmankwati complained that she had not bonded with the unborn child, and that it felt as though she was carrying a stranger inside her.

According to Mmankwati's mother, a staunch Christian, the forefathers would harm Mmankwati and her family if the child were to be given up for adoption, and were allowed to leave the family.

Mmankwati and her two children were financially dependent on her mother. Counselling was unsuccessful, in the sense of deconstructing religious and cultural discourses in order to liberate women to make healthy decisions about their bodies.
Mmankwati prepared to give birth to a child whose father had raped her, whilst she herself was uncertain about the financial future of her family and her emotional future with the child.

\section{Traumatised by culture and church: Trapped in an abusive relationship}

Khumo's son, Sifiso (18), stole his mother's belongings. He also played truant, had bad friends, did not want to go to church, told lies, smoked dagga (marijuana), damaged his mother's clothes, belonged to a gang, and in turn was harassed by other gangs, did not care about personal hygiene, ate only takeaways, and left condoms lying around.

Moreover, Sifiso beat up his mother whenever she did not give him what he wanted or tried to discipline him. Sifiso had been diagnosed as suffering from bipolar manic-depressive disorder, but did not take the medicine prescribed for him.

Khumo, a domestic worker, had been advised by her employer to obtain a protection order against the child. However, Khumo considered this to be 'Western' and to propagate human rights, which was against her upbringing. Her culture and her church told her that what she was experiencing was the fate of a mother, and not to cut ties with her child, even if she herself was in danger.

Khumo was a committed Christian but believed that a sangoma had placed a curse on her, hence her son's abusive behaviour.

Surprisingly, Sifiso attended a counselling session with his mother. Careful and prolonged deconstruction of the demands of a variety of cultures on the lives of Sifiso and his mother was performed. Of significance here were the demands made on Sifiso by his peer group. Sifiso needed a cell phone, designer clothes, money for drugs, and a girlfriend. And if his mother could not give him these things, he stole from her or sold her belongings. If his mother locked away her belongings, he beat her.

In counselling Sifiso and Khumo started to redefine the mother-son relationship. Sifiso regarded a mother as one who gives, according to his needs as defined by the peer group. Khumo regarded motherhood as being respected by her son, who should spend his time studying and working to eventually provide for his mother, according to the culture and the church in which she grew up. It was not an easy process, and definitely not one that guaranteed success, but eventually Sifiso and Khumo redefined their relationship, as one in which they potentially make each other strong by walking together through life as partners, and not as opponents.

\section{Traumatised by a sangoma's curse}

On a particularly busy day at the hospital, Nomusa, Motle and Pula agreed to small-group counselling instead of individual counselling. It turned out that although they 
were experiencing different problems they offered the same explanation for their misfortunes, namely, that they had been cursed by a sangoma. The women, incidentally, were devoted Christians, two of them belonged to a born-again church, and the other to a mainline church. All three of them were educated and employed.

Nomusa's husband had died in a motorcar accident. According to Nomusa he had been of Swati royal descent, which allowed him to marry four wives, but he had chosen to marry Nomusa only. Nomusa believed that that was why other women had a curse placed on him and her. That also was the reason why he had died, and why men were no longer interested in her, but were rather afraid of her. Nomusa belonged to a born-again church, 'Conquerors Ministry'. She slept with her Bible to protect her against the curse, but that did not seem to take away her fears and anxiety.

Motle had lost her sexual desire, causing her husband to leave her. Motle believed that her husband's girlfriend had cast a spell on her through a sangoma. She thought that that was why she had found snakes and animal excrement in her yard. At night she woke up with wetness in her lap, and once she woke up with razor blades between her breasts. Motle belonged to the 'Universal Church', where she was told that she could drive out the demon by praying and fasting for seven days.

Pula was a divorcée. Her boyfriend came and went, that is, he came, ate, slept over, and then left for an undetermined period, causing Pula great emotional stress. Pula had been advised by Nomusa and Motle that a sangoma had cast a spell on her. In order to break this spell, she needed the services of another sangoma, but she did not have the money to pay for those services. Pula belonged to a mainline church, the Uniting Reformed Church in Southern Africa (previously called the Dutch Reformed Church in Africa). She bemoaned the fact that the church did not wish to deal with the spell but simply told her to stop believing in such heathen ideas.

During counselling, there was no undermining of the patients' belief in the sangoma's curse. The patients' histories were mapped and past instances were highlighted when they had withstood the sangoma's curse, for instance based on the belief in the power of a benevolent God. The binaries of Western Christianity and a cultural belief in heathen customs were undermined and deconstructed towards a preferred way of religiousness, whilst dealing with the challenges of cultural beliefs.

\section{Torn between church, culture and human rights}

Lerato (39) visited the Family Medicine Clinic of Kalafong Hospital, complaining of severe headaches. She was referred for counselling.

Lerato belonged to a born-again church in Mamelodi, a township outside Tshwane. She worked at a chain store for a small salary, which left her with almost nothing after deductions.
Lerato's story was as follows, her mother was a sangoma who wanted to steal the Holy Spirit from Lerato in order to practice magic. Also, Lerato's mother had cast a spell on Lerato's sister by instilling a matrix (a virtual reality) in her. The matrix had kept the sister from obeying and respecting the pastor of the born-again church, also attended by Lerato. The matrix additionally caused Lerato's sister to constantly dream about snakes coming out of her (the sister's) vagina and mouth. However, when the sister was baptised by the pastor, the matrix left her, and the dreams stopped.

Lerato's daughter had been raped by the stepbrother of Lerato's mother when she was five years old. The daughter, now a 13-year-old teenager, wished to wear modern and close-fitting clothes. The pastor advised Lerato to give the child a 'good spanking', in accordance with Proverbs 22:15, lest she invites being raped again. After punishing her daughter a second time with a sjambok, for wearing revealing clothes, Lerato was informed by the school that, because of the severity of the punishment, they would lay a charge of assault against her if ever she were to beat the child like that again.

Lerato was obviously torn between religious and cultural discourses, as well as human rights. Deconstructing the binaries in Lerato's life was not easy. Also, Lerato was unable to attend further counselling sessions because her employer did not consider counselling a good reason for giving leave of absence from work. The challenge was to move towards an alternative story in which healthy religious values, according to Lerato, played an important role amid cultural demands, as well as the inculturated values of the indigenous church to which she belongs and the secular values of human rights. The focus was especially on reshaping the 'unconditional obedience' expected from her by her church, and from her child by herself, towards 'worthiness in the eyes of God and humankind'. Lerato found some relief in exploring human worth and dignity in the spaces between secular human rights on the one hand, and religious views on the relationship between God and the believer on the other, although her church does not really allow her to do so.

\section{Traumatising sex in a religious perspective}

Kobie (71) was a White Afrikaans woman who belonged to the Dutch Reformed Church. Her husband demanded anal sex from her, causing her intense physical pain, and keeping her from recovering after a hip-replacement operation.

Kobie said that it was against her convictions to have anal sex. According to her culture, decent people did not commit acts like that. On the other hand, Kobie's religious convictions put her in jeopardy as far as her commitments towards her husband were concerned. Firstly, she believed that it was against the Bible for a wife to refuse to have sex with her husband. Secondly, she believed that the Lord wished her, through this matter, to reach the soul of her husband, who was a non-believer. Thirdly, she also believed that God was punishing her for having been pregnant with her husband's child when she married him. 
During counselling the cultural and religious boundaries drawn for Kobie as a woman vis-à-vis sex, were shifted. Kobie experienced major relief when she became convinced that as a woman she could make choices as far as her sexuality was concerned, even at that stage, when she was in her seventies. However, her husband forbade her to attend any more counselling sessions, and Kobie's right to draw her own boundaries was taken away from her.

\section{Conclusion}

In the stories above, reference was made to women who were traumatised and who had experienced severe ongoing tension because of their cultures' (both Black and White) notions about illness and healing. Sometimes the teachings of the women's churches, which included both mainline and indigenous churches, on what makes one ill and on what can heal the believer, intensified their trauma and inner tension.

Incidentally, all the above stories were about women for whom boundaries had been drawn by their cultures and churches to control their intimate lives. There was the story of a pregnant woman's trauma of carrying a dead child inside her, and of other pregnant women expecting children whom they financially could not afford to raise. The teachings of their cultures and churches on adoption and abortion intensified their anxieties and trauma. There were also stories about women whose sexuality was controlled by culture and religion in a way that traumatised them. Finally, there were stories about women trapped in abusive relationships with their children and partners, and who were prevented from liberating themselves from their trauma by culture and religion.

In the end we learnt how, in most cases, these women in counselling found new ways of becoming a cultural and religious being, but with dignity and worth. Without doing away with either culture or religion, the women found ways of exploring the healthy aspects of religion and culture, and, thus, through indigenous ways of healing, they found relief from their trauma and tension.

\section{Acknowledgements Competing interests}

The author declares that she has no financial or personal relationship(s) which may have inappropriately influenced her in writing this article.

\section{References}

Bergin, A.E., 1988, 'Three contributions of a spiritual perspective to psychotherapy and behaviour change', in W.R. Miller \& J.E. Martin (eds.), Behavior therapy and religion, pp. 25-36, Sage, Thousand Oaks, CA.

Lovinger, R.J., 1990, Religion and counseling: The psychological impact of religious belief, Continuum, New York.

Miller, G., 2003, Incorporating spirituality in counseling and psychotherapy, Wiley, Hoboken, NJ.

Oats, W.E., 1970, When religion gets sick, Westminster, Philadelphia, PA. 